Chapter 14

\title{
A comparative appraisal of recent and proposed changes to the fire and rescue services in England and Scotland.
}

\author{
Pete Murphy, Katarzyna Lakoma, Kirsten Greenhalgh and Lynda Taylor
}

\begin{abstract}
The regimes for developing policy, delivering services and providing assurance to the public for Fire and Rescue Services in Scotland and England have diverged significantly since 2010, facilitated by the devolution of responsibility for local public services to the Scottish Government. This divergence has generated an opportunity to compare two service regimes that for over a hundred and fifty years shared the same antecedents and history. Previous studies have individually explored the antecedents and the first five years of the development in each of the two countries between 2010 and 2015 (Taylor et al 2018, Murphy and Ferry 2018). This chapter presents a comparative appraisal of more recent and proposed changes to the fire and rescue services in England and Scotland and brings the narrative up to 2018. The catalyst for this new appraisal has been the publication of a series of key policy documents in both countries, which suggest it is both timely and opportune to undertake a further comparison of the two countries arrangements.
\end{abstract}

Key Words

Fire and Rescue Services, Policy Development, Service Delivery, Public Assurance, England Scotland. 


\section{Introduction}

Scottish firefighters and fire brigades have been an integral part of the fire services in the UK since James Braidwood established the first municipal service in Edinburgh. He was the first to develop systematic methods of controlling and fighting fires rather than simply (and sometimes chaotically) responding to individual incidents (Ewen 2010). Braidwood went on to establish the London Fire Engine Establishment in 1833, which was the precursor to the Metropolitan Fire Brigade of 1866. As Taylor et al (2018) acknowledge "from the early $19^{\text {th }}$ century to the end of the $20^{\text {th }}$ there was little to differentiate the scale, scope and nature of the service in Scotland from those south of the border, as the Edinburgh 'model' was adopted by in all the great Victorian cities, such as Glasgow, Manchester, Liverpool, Birmingham, Leeds and many more".

The heart of the early $21^{\text {st }}$ century modernization of the fire service by the New Labour administrations, and the subsequent development of policy and service delivery was the Fire and Rescue Services Act 2004 and the Civil Contingencies Act 2004. These two acts were developed and came into force at the same time. Scotland actually had its own Fire and Rescue Services Act of 2005, but this is almost identical to the English Fire and Rescue Services Act 2004 in terms of principles, objectives and the extensive changes to policy and practice that followed the commencement of the act.

At this time both systems changed the basis for their assessment of risk from a system based primarily on evaluating risks to premises, buildings and property, to a system based upon evaluating risks to people and communities (Bain et al 2002). Amongst other things, the act introduced an Integrated Risk Management Planning process (IRMP) together with Integrated Risk Management Plans, which by statute have to be produced and regularly updated in both countries. Although a great number of changes have subsequently happened to the fire service in both England and Scotland, the one thing that has not changed in either service since its introduction is the requirement to assess risk based on an IRM process and the requirement to produce and IRM plan.

\section{Financial Resources}

Both regimes and administrations have also been subject to the same severe financial constraints under the Coalition governments' macro-economic approach to 'austerity' (Blyth, 2015; O'Hara, 2015; Schui, 2014). This was a UK wide policy, that has been operationalized at service and local level through successive financial settlements and shortterm cutback management.

Although the policy of cutback management (Wilks 2010; Scorsone and Plerhoples 2010) was intended to be 'short term' and originally intended to address the 'structural deficit' in the UK's finances, it has persisted since the emergency budget and the Governments' Spending Review of 2010. Cutback management is usually a short-term policy response to major spending shocks or crises last seen in the UK in the 1980's. It is questionable whether it is an efficient or effective policy in the short term, there is no doubt that it is an inefficient long-term economic policy. It has been implemented in the UK through a series of short term sub-optimal adjustments instead of a coherent and robust long-term strategic 
approach. The result has been an increase in the aggregate of national debt, which exceeded $\mathrm{f1.5}$ trillion at the end of the 2015-16 financial year (HMT 2018a).

The governments' long-term single departmental spending plans as originally laid out by the Spending Review (HM Treasury 2015) for the period 2015 to 2020 include those of the Home Office (Home Office 2016a). These plans described the new government's objectives, and are intended to ensure that each governments department's plans and spending reflected the priorities of the 'whole of government' priorities. The departmental expenditure limits for the Home Office in England and for Scotland and Wales are shown (in cash terms and in billions) in table 1 below. They effectively show a medium-term reduction in cash terms, and a greater reduction in real terms, for public services in both countries both recently and in the foreseeable future.

Table 1: Resource DEL excluding depreciation) 2015 Spending Review Departmental Expenditure Limits (HM Treasury p77).

\begin{tabular}{|l|l|l|l|l|l|l|l|}
\hline $\begin{array}{l}\text { Departmental } \\
\text { Expenditure Limit }\end{array}$ & $\begin{array}{l}2015- \\
16\end{array}$ & $\begin{array}{l}2016- \\
17\end{array}$ & $\begin{array}{l}2017- \\
18\end{array}$ & $\begin{array}{l}2018- \\
19\end{array}$ & $\begin{array}{l}2019- \\
20\end{array}$ & $\begin{array}{l}2020- \\
21\end{array}$ & $\begin{array}{l}\text { Cumulative } \\
\text { Real Growth }\end{array}$ \\
\hline Home Office & 10.3 & 10.7 & 10.6 & 10.6 & 10.6 & $*$ & $-4.8 \%$ \\
\hline Scotland & 25.9 & 26.1 & 26.3 & 26.3 & 26.5 & $*$ & $-5.0 \%$ \\
\hline Wales & 12.9 & 13.0 & 13.1 & 13.2 & 13.3 & $*$ & $-4.5 \%$ \\
\hline
\end{tabular}

Although these departmental plans were updated in December 2017 (Home Office 2017a), together with the latest annual 'supply' estimates presented to the House of Commons by HMT in April 2018 were still based upon the 2015 Spending Review and the latest 'Spring Statement' in March 2018 (HM Treasury 2018b) made no new spending announcements.

Thus the 'resource envelope' upon which the fire and rescue services is dependent in both countries in the period from 2010 to 2018 and in the foreseeable future up until 2020/21 is remarkably similar. It is diminishing.

\section{A watershed}

The common approach to policy and the delivery of fire and rescue services changed radically after the election of a Conservative led Coalition Government in England in May 2010, and First Minister, Alex Salmond launched the Christie Commission on the Future Delivery of Public Services in Scotland (Scottish Parliament 2011a).

The latter was to examine how Scotland's public services could be delivered in order to secure improved outcomes for communities across the country. The following year, the 
Scottish National Party won the May 2011 elections to Holyrood with an overwhelming majority. The Christie Commission (2011) produced its report with the chairman Dr Cambell Christie urging the government to "act quickly and decisively" claiming that "the way forward is clear, and it is now essential that the Scottish Government exercises its leadership by initiating a fundamental public service reform process".

The period from 2010 to 2015 then saw considerable changes to public policy and management as well as service delivery across the whole public sector throughout the UK. Nowhere was it better exemplified by the respective changes in the two Fire and Rescue sectors. The next three sections of this chapter will therefore compare changes inthe policy development, service delivery and public assurance arrangements in England and Scotland, before drawing some conclusions in the final section.

\section{Policy and Leadership}

The fundamental differences in the policy approach to fire and rescue services was almost immediately apparent from the first policy documents published after the respective elections in 2010 and 2011. Both governments proposed new legislation, and initiated consultation exercises. These resulted in new legislation and the issuing of New National Frameworks for Fire and Rescue services based upon competing visions of public services. Policy development at both national and local levels changed and has continued to contrast between the two countries.

In Scotland the Christie Commission had focussed on how to secure improved outcomes from public services. The Scottish Government was urged to show leadership and "act quickly and decisively" to improve public services.

Before the end of 2011, and benefiting from all party general support, the Scottish Government had published a consultation on the future of the Scottish Fire and Rescue Services (Scottish Government 2011a); an initial options appraisal on possible structural reform (2011b), and an Outline Business Case for the creation of a single national services (Scottish Government 2011c). The latter to be through the amalgamation of the eight existing services and the national training centre which had quickly become the preferred option.

These were followed by the 2012 Police and Fire Reform Act (Scotland), which required the establishment of a single national service by April 2013, when a national policy framework (Scottish Government 2013a) and a new governance and accountability framework for fire and rescue services (Scottish Government 2013b) were also published. In retrospect, it is clear that the Scottish Government took an immediate grasp of fire and rescue service policy, and sought to develop it in an open collaborative manner reminiscent of earlier calls in England for the co-production of public policy.

This practice of collaboratively producing policy with the services and organisations that had to deliver the policy, and allowing significant time for public consultation and reflection upon representations received, is one that has endure into the latest round of national policy. At the time of writing this chapter, the Scottish Parliament are in the course of 
undertaking 'Post legislative scrutiny of the Police and Fire Reform (Scotland) Act 2012' (Scottish Parliament 2018). Audit Scotland (2018) have published an update of their audit report on the first two years of the fire and rescue reforms (Audit Scotland 2015). The Scottish FRS are consulting on their future strategy, (SFRS 2018) and HM Fire Service Inspectorate, partly motivated by the Grenfell tragedy, have completed a national Fire Safety Enforcement Inspection (HMIFSI 2018).

What emerges from all of this activity is not only the continuing difference in policy content and underlying principles, but also the difference in the way the processes are being conducted.

The open, consultative, inclusive and reflective process in Scotland contrasts with the equivalent in England. In England third parties find it difficult to contribute to the process. The consultation periods have been as limited as statute allows; and key national policy documents such as a draft new National Framework (Home Office 2017) are published to a 'silent fanfare of absent publicity' (Murphy and Glennon 2018). To be followed almost immediately by a National Framework (Home Office 2018) that has taken a minimal amount of notice of the limited response.

In their analysis of the period up to 2015, Taylor et al (2018) noted that the early initiatives reflected a strong orientation towards notions of public value, new public service theory and traditional interpretations of public service (2018, p194), where the users of public services are seen as citizens with responsibilities as well as rights, rather than 'customers' of services. They also give the impression that the publics' voice is both valued and is heard and acted upon.

The latest policy documents embrace and further embed these notions as the government attempts to operationalise the next stage of service reform and build on the approach adopted over the reforms to date. Scotland, at least in terms of its Fire and Rescue Service, has witnessed a successful start to its transformation project that has demonstrated individual and collective leadership within a strategic and holistic approach to the service (Taylor et al 2018, Audit Scotland 2015, 2018).

"Board and management display mutual respect, a constructive tone and genuine shared ownership of issues" (Audit Scotland 2018 p. 5).

Finally, at the local level, policy development, partnership working and community working continues to be effective (Audit Scotland 2015, 2018, Taylor et al 2018).

"The SFRS has successfully maintained effective relationships at a local level through local senior officers (LSOs) who liaise with the 32 Scottish councils and community planning partnerships. The council officers and councillors that we interviewed during our audit consistently said that they valued the enthusiasm and contribution of the LSOs very highly, particularly in relation to their community work on prevention and protection.

LSOs lead the development of local fire and rescue plans for each Community Planning Partnership. These plans are more tailored to local risks than previous 
plans and are focused on improving outcomes for local people, such as better home safety." (Audit Scotland 2018 p 23).

In England, policy development took a different turn from the moment the new Fire Minister in the Coalition Government announced a strategic review of the fire and rescue sector and the governments' role within it (DCLG 2010). A new policy regime for public services that has been described as 'austerity localism' (Lowndes and Pratchett 2012) was established by the Localism Act 2011 and the Open Public Services White Papers (Cabinet Office 2011, 2012). This was a return to the notions of new public management, neoliberalism and the advocacy of greater exposure of public services to markets and price competition. The emergency services were no exception.

The National Framework for Fire and Rescue Services that followed (DCLG, 2012) included a significantly reduced role for the government in policy development and support for the delivery of fire services (Murphy and Ferry 2018). This was accompanied by a significant loss of capacity and coherence in the sector which compromised strategic alignment at the national level (Ferry and Murphy 2015, NAO 2015). The government also abolished the Audit Commission and most of the 'improvement' infrastructure, losing significant amounts of data and intelligence in the process. At the local level it introduced a 'light touch' selfgoverning model for local fire and rescue authorities, and implemented a commissioner/provider split with the fire and rescue service.

The result was effectively an abdication of individual and collective leadership by the government, with only limited and unplanned restructuring of service delivery, as only two pairs of county service amalgamations took place at the local level despite continuous policy encouragement. By the time of the general election in 2015 the system was in disarray and quickly became unacceptable to both parliament and the government.

In 2016 the Public Accounts Select Committee had reported

"The Department for Communities and Local Government has not had a strong understanding of the capacity of individual fire authorities to absorb further reductions through efficiency savings, or of the impact of reducing fire prevention work. By not providing more active support and guidance, the Department exacerbated the risk that fire authorities would miss opportunities to improve value for money'........'There are weaknesses in the local scrutiny by fire authorities which raise concerns about their operational performance and safeguarding value for money; this is more serious because of the lack of an external inspectorate.." (2016 p3).

The government announced that responsibility for Fire and Services would henceforth be transferred to the Home Office, and in one of her last speeches as Home Secretary the future Prime Minister admitted

'fire and rescue landscape are still beset by poor governance and structures (they are) a service that requires further reform to improve accountability, bring independent scrutiny and drive transparency' (Home Office 2017) 
Theresa May's proposed solution was to adopt the approach that she had previously taken to the reform of the police services with the introduction of Police and Crime Commissioners who would now ('subject to a local case being made') be encouraged to take over governance and policy responsibility for local fire and rescue services. She therefore announced that amendments would be added to the Policing and Crime Bill, then at third reading in the House of Commons, accepting and incorporating all of the recommendations of the PAC report.

To examine how policy changed as a result we need only look at the new National Framework for Fire and Rescue Services (Home Office 2018) that was published after the Policing and Crime Act 2017. We have of course already commented on the process adopted and the limitations of the consultation arrangements. What the framework includes and what it excludes are both instructive.

There is no mention in the minister's foreword to the framework or in its' introduction, of the National Audit Office or Public Accounts Committee reports, that drew attention to inadequacies in the sponsorship, leadership, financial control and infrastructural support for the service. There is also, no explicit mention of the long-term planned future reductions, in financial support. The new framework is however very clear that the governments overall policy approach has not changed.

"The National Framework will continue to provide an overall strategic direction to fire and rescue authorities, but Whitehall will not run fire, and fire and rescue authorities and their services remain free to operate in a way that enables the most efficient and effective delivery of their services, drawing upon their considerable skills and experience to best reduce the risks from fire". (Home Office 2018).

The framework re-confirmed that the basis of policy development would remain the IRMP process. Similarly, it asserted that the role of national government in the national resilience arrangements is to identify any gaps in provision. It remained the responsibility of fire and rescue authorities to assess all foreseeable risks that affect their communities, whether they are local, cross-border, multi-authority and/or national in nature from fires to terrorist attacks, and to address any gaps.

While the act and the framework clearly acknowledge the services contributions to wider social policy issues and wish to encourage wider collaborative working, both the act and the framework are primarily concerned with changes in the arrangements for public assurance and service delivery rather than public policy.

\section{Service Delivery}

There are a number of characteristics or issues relating to service delivery through which we can compare the two countries. Management and performance; ways of working; the priority afforded to protection and prevention as opposed to reactive services, and of course, the governance and delivery structure. 
The clear contrast in the service delivery structure is the simplest to describe in the two countries.

The amalgamation of services, primarily to achieve economies of scale and make more sophisticated specialist services and appliances universally available had been a recurrent feature in both countries, since 'modernisation' at the turn of the century.

John Prescott, the politician most responsible for the Fire and Rescue Act 2004 and the Civil Contingencies Act when he was Secretary of State and Deputy Prime Minister, was often accused of trying to apply his regional agenda to all public service reform and the fire and rescue service was no exception. His project to replace 46 local fire control centres with nine purpose-built regional centres was a particular disaster that became a political albatross for regionalisation long before and after the scheme had to be abandoned (NAO 2011, PAC 2011). The coalition government however remained committed to encouraging voluntary amalgamations. So much so that in 2015 Lyn Brown MP, then shadow fire minister published a consultation about the future of fire services in England that was based explicitly on three options for the horizontal integration and amalgamation of services (Brown 2015).

This did not happen in England. In Scotland, however horizontal integration across the sector had all-party support in principle and ultimately resulted in the creation of the Scottish Fire and Rescue Service, which is the largest service in the UK and the fourth largest in the world.

There are however, three aspects of service delivery that have remained constant across both countries, although even in these areas there are minor differences starting to appear. The first is a firefighting establishment with a mixture of service personnel consisting of whole-time, part time (or 'retained') personnel and volunteers. The second is the deployment of this personnel via the 'watch' and station structure, and the third is the need for collaborative working both across the emergency services and more widely with key partners such as local authorities.

These three aspects reflect almost universal characteristics of fire services across the globe. Although, both countries share these characteristic the approach to flexible rostering of personnel; the use and retention of stations and other premises, and the nature of their collaborations is starting to change because of policy differences.

Scotland is effectively implementing a resource or asset-based strategy - valuing its assets and attempting to optimise its use of available resources while evaluating inputs, outputs and outcomes against the creation of both public and private value. England, as the new national framework (Home Office 2018a) and the new inspection proposals demonstrate (HMICFRS 2018), is implementing a financially-led strategy, through a shrinking resource envelope, allied to evaluating services and initiatives against the financial return on investment primarily (but not exclusively) in the short term. Scotland is essentially retaining assets and estate and seeking to make better use of them, often in collaboration with the other emergency services, England is actively rationalising and disposing of its assets and estates, where possible, to meet financial targets. 
The second emerging difference results from the balance of investment within the respective services and countries, in terms of investment in national and local 'protection and prevention services' on the one hand, and fire response services on the other.

Both countries acknowledge the importance of maintaining fire protection and prevention services, and overall, both services are subject to approximately the same level of reducing resources. However, in terms of proportionate reductions, the overall balance tends to favour investment in emergency response in England, while in Scotland it favours the protection and preventative services as a result of alternative service and financial policies between the two countries.

In terms of collaborative working, the service in England is clearly moving towards much closer collaboration with the police in particular, although the government was so concerned about the extent of collaboration across the emergency services that it introduced a statutory requirement to collaborate in Chapter 1 of the Policing and Crime Act 2017.

In Scotland collaboration between the government, the SFRS, the emergency services and other key stakeholders such as the local authorities has been relatively successful and is considered to be improving. The geographical co-terminus boundaries between police, fire and ambulance services in Scotland undoubtably help collaborative working at the strategic level, while coterminous boundaries with local authority areas clearly assist operational collaboration.

Finally, we are able to compare the management and performance of the two countries services as both have been subjected to extensive external independent scrutiny and review over the last eight years, not least by their external auditors (NAO 2015a, b, Audit Scotland 2015,2018 ), but also by their respective parliamentary scrutiny arrangements (PAC 2016, Sottish Parliament 2011b, 2018).

In terms of both financial and service performance the contrast is surprisingly stark.

While Scotland has been characterised as having strong financial management with a 'good approach to long term financial management' (Audit Scotland 2018 p.5), in England the NAO (2015) found significant inadequacies in financial management and value for money, which were reiterated by the PAC (2016) and acknowledged by the government (Home Office 2016b).

In Scotland, the auditors initially reported that the Scottish Government and the Scottish Fire and Rescue Service managed the 2013 merger of the eight fire and rescue services effectively and that there was no impact on the safety of the public during or as a result of the merger. There were no additional funds to help with the merger but nevertheless in the first phase from 2013 to 2015 the performance of the Scottish Fire and Rescue Service's improved and was continuing to improve (Audit Scotland 2015). By 2018 the auditors were still positive if more cautious 'the SFRS continues to deliver emergency and prevention service while progressing a complex and ambitious programme of reform' (2018 p1). Audit Scotland was however, by this time inter alia calling for an increase in the pace of reform; 
the introduction of well-developed performance management systems, and more robust monitoring evaluation and reporting of the impacts of community safety activity.

\section{Public Assurance}

In Scotland, there is a comprehensive system of parliamentary and governmental scrutiny over the fire and rescue services. The government appoints an arms-length independent board, who are responsible for the corporate governance of the SFRS. The senior management of SFRS reports to the Board and they in turn are accountable to the Scottish Government through the Department of Community Safety who are, inter alia, responsible for 'delivering fit-for-purpose police and fire services'. The external audit is the responsibility of Audit Scotland who now audit 224 public bodies including the Scottish parliament central government bodies, the 32 councils and the 23 NHS bodies.

Parliamentary scrutiny in Scotland is largely based on the Westminster system which is a model of scrutiny through a series of all-party backbench select committees that largely mirror government departments. The fire service in Scotland is scrutinised primarily by the Local Government and Communities Committee but, as in England, can be called upon by other select committees. In addition, Scotland also has a Public Audit and Post-legislative Scrutiny Committee. This committee scrutinises the performance of the Scottish Government and public bodies; considers issues arising from their accounts and specifically reviews the implementation and effectiveness of recent legislation. As mentioned earlier the Local Government and Communities Committee is currently scrutinising Building Regulations and Fire Safety in Scotland, largely as a result of the Grenfell Tower disaster, (Grenfell Tower Inquiry 2016) while the Public Audit and Post-legislative Scrutiny Committee is investigating issues arising out of the 2018 Audit Scotland update of the Scottish FRS (Audit Scotland 2018).

In England, since 2016, the Home Office has been responsible for the fire and rescue services. However, the Minister of State for Policing and the Fire Service in his forward to the new national framework states that the national framework will continue to provide an overall strategic direction to fire and rescue authorities. 'Whitehall will not run fire' thus signalling a continuation of the policy and practice that was evident from 2010 to 2015 under the previous Department of Communities and Local Government (Home Office 2018a).

The Home Affairs Committee and the Public Accounts Select Committee provide parliamentary scrutiny, although both of their remits are much wider than their Scottish counterparts. Fire and Rescue services are therefore a much smaller part of their respective portfolios. For example at the time of writing, the Home Affairs committee has fourteen ongoing inquiries none of which involve the fire and rescue service while the PAC has twenty nine ongoing inquiries with the only one affecting fire and rescue a review of the process for replacing the 'Airwave' emergency communication system.

Fire and Rescue Authorities in England can appoint their own auditors who cover the authority's financial statements and the assessment of value for money under the Local Audit and Accountability Act 2014. The act only applies to England where the audit of 
organisational performance has increasingly relied on the development of the concept and practice of 'armchair auditors' or interested members of the public taking direct evaluative interest in services rather than regular public assessment and reporting from professional auditors. There is now considerable independent research to question the effectiveness of this reliance on 'armchair auditors' (Ferry and Murphy 2017, Ferry et al 2018).

In a speech shortly before she became Prime Minister, Theresa May promised to put in place the right framework of institutions and processes to ensure operational integrity, as well as greater accountability and transparency for the fire service (Home Office 2016b). She referred in particular to the lack of an independent inspectorate, a regular audit of performance, and the limited available data on performance over time or between areas.

External independent inspection of the fire and rescue service was terminated on the announcement of the abolition of the Audit Commission. The Audit Commission had taken over independent inspection from Her Majesty's Fire Service Inspectorate in 2007. Between 2007 and 2018 England was the only country in Europe without an Inspectorate. Scotland had retained Her Majesty's Fire Service Inspectorate for Scotland throughout.

Shortly after the Policing and Crime Act 2017 received Royal Assent, the minister (Brandon Lewis) announced further details about the new Inspectorate (Home Office 2017c). He said that a new 'suitable' inspectorate for fire and rescue services would be modelled on Her Majesty's Inspectorate of Constabulary (HMIC), and that, like HMIC, it would have a focus on efficiency and effectiveness.

It would have the power to undertake joint inspections with HMIC, and thematic inspections as well as organisation inspections and service inspections. Like HMIC, it would report to government through the Home Office. The Home Secretary has the power to commission and direct inspections and the Chief Inspectors' annual report will be presented to Parliament via the Home Office.

Emerging as Her Majesty's Inspectorate of Constabulary and Fire \& Rescue Services it was established in April 2018 with a Chairman and Board inherited from its predecessor the HMIC.

Any ambitions for robust independence were further deflated with the publication of the consultation on the new inspectorates' proposed inspection framework and initial programme of inspections (HMICFRS 2017). Emulating the practice adopted by the Home Office with the National Framework, it was published in the week immediately prior to Christmas in 2017 (Murphy and Glennon 2018). Following a minimal statutory consultation process that took little notice of the limited representations received, it was quickly followed in March 2018 by the formal framework (HMICFRS 2018).

In Scotland, the Chief Inspector (HMFSI) is appointed by Order in Council and operates independently of Ministers and the SFRS.

The purpose of the Scottish Inspectorate is to 'give assurance to the Scottish people and to Scottish ministers that the Scottish FRS is working in an efficient and effective way and to promote improvement in the SFRS'. The Inspectorate has to have regard to 'the principles of 
public focus, independence, proportionality, transparency and accountability'. By statute, the Chief Inspector has a duty to make 'independent' determinations and is obliged to collaborate and align the work of the inspectorate with key stakeholders such as Audit Scotland, the Ombudsman and the Procurator Fiscal Service.

The Scottish Inspectorate is conceptualised and established as part of the scrutiny arrangements of governance rather than being part of the government. The new HMICFRS in England is clearly conceptualised and strategically positioned closer to the government. Although it is too early to judge in this case, history suggests that the more independent an inspectorate is, the more robust open and effective the scrutiny it provides.

Mrs May speech in 2016 also drew attention to the limited available data on service performance available to the government, key stakeholders, collaborators and the public. Some would regard this as a tacit acknowledgement of the failure of the armchair auditor initiative. The loss and degradation of performance data and intelligence has been an issue since the announcement of the demise of the Audit Commission. It was further exacerbated by the closure of the Improvement and Development Agency and a range of nondepartmental public bodies that were part of the so-called 'Bonfire of the Quango's' (Ferry and Murphy 2015, NAO 2015a, Murphy et al 2018). As a result, of these changes there was a huge loss of publically available data, intelligence and historical knowledge, and an irreplaceable back catalogue of individual reports and inspections. In addition the tools and techniques, capacity and capability to analyse and interrogate this information was also lost.

\section{Conclusions}

In retrospect, it appears somewhat ironic that the policy priority in Scotland of improving public services and in particularly improving outputs is consistent with the policy emphasis in England prior to the 2010 general election. Horizontal integration to achieve economies of scale and greater efficiencies were an ambition of the New Labour administrations in England. Indeed some of the changes in Scotland might well have emerged as a logical next stage or at least a policy options in England had the general election not intervened.

Similarly, the ambition to integrate local policy objectives, and align organisational activities, across locally delivered public services, via for example Local and Multi Area Agreements, was a characteristic of previous labour administrations. These initiatives were soon abandoned in England after 2010, but found further expression in Scotland through Single Outcome Agreements and community planning. At a more general level, this appears to reflect greater active involvement from central government in service delivery. Scotland also appears to have a more, reflective and responsive approach to policy development and service delivery not least in terms of 'ownership' of issues.

Changes in the structural and organisational landscape in both countries is the most visible contrast between the two countries in terms of service delivery. It will be interesting to see whether the emerging contrasts between estates strategies; the balance of investment between preventative and reactive services, and the alternative approaches to collaboration continue to widen and if so, what impact this has on service management and performance. 
What surprised the authors, of this study is how little evidence there appears to be, of mutual learning between the respective regimes.

The crucial issue is how well the services are performing, how efficiently they are spending the publics' money and ultimately how safe their communities are as a result.

The current evidence may be limited, but the findings of our investigations tend to favour the approach in Scotland. And this is the case even if you allow for competing objectives.

It is clear that England has financial management and expenditure targets as its central priority. Yet, in value for money term; and in terms of financial targets, (which are equally challenging in both countries), it is Scotland that appears to have been more successful todate. Whether the changes emerging from the Crime and Policing Act 2017, and the new national framework in England have a positive or negative impact on this comparison is a matter for a future study.

Finally, in terms of public assurance, we found clearer lines of accountability between the government and the service; more and more focussed parliamentary, national and local scrutiny; and more robust and effective frameworks for inter-agency working in Scotland than exist, or are emerging in England.

\section{References}

Audit Scotland. 2015. Scottish Fire and Rescue Service, Audit Scotland: Edinburgh.

Audit Scotland. 2018. Scottish Fire and Rescue Service An update, Audit Scotland: Edinburgh.

Bain. G, Lyons. M, and Young. M (2002) The future of the Fire Service; reducing risks saving lives: the independent review of the Fire Service Norwich: TSO.

Blyth, M. 2015. Austerity: The history of a dangerous idea, Oxford: Oxford University Press.

Brown, L. 2015. The future of Fire and Rescue Services in England

Cabinet Office (2011) Open Public Services White Paper. London: Cabinet Office.

Cabinet Office (2012) Open Public Services White 2012. London: Cabinet Office.

Christie Commission. 2011. Commission on the future delivery of public services. Norwich: TSO.

DCLG. (2010). Leading a lean and efficient fire and rescue service, Fire Minister Bob Neill's speech to Fire and Rescue 2010 Conference, Harrogate, England.

DCLG. 2012. Fire and rescue national framework for England. London: TSO.

Ewen. S. 2010. Fighting Fires: Creating the British Fire Service 1800-1978. Basingstoke: Palgrave Macmillan.

Ferry, L. and Murphy, P. 2015. Financial sustainability, accountability and transparency across local public service bodies in England under austerity. Report to National Audit Office (NAO). 
FERRY, L. and MURPHY, P., 2017. What about financial sustainability of local government!-A critical review of accountability, transparency, and public assurance arrangements in England during austerity. International Journal of Public Administration. 41, (8). 619-629.

Ferry, L, Glennon, R, and Murphy, P. 2018. Chapter 3: Local Government in Public service accountability: rekindling a debate. Cham, Switzerland: Palgrave Macmillan.

Grenfell Tower Inquiry (20160 Ongoing. Available at https://www.grenfelltowerinquiry.org.uk/ [Accessed 18/09/2018]

HM Fire Service Inspectorate. 2018. Fire Safety Enforcement by the Scottish Fire and Rescue Service. Edinburgh: HMFSI.

HMICFRS. 2017. Proposed fire and rescue services inspection programme and framework 2018/19. London. HMICFRS.

HMICFRS 2018 Fire and rescue services inspection programme and framework 2018/19. London: HMICFRS.

HM Treasury. 2015. The Spending Review 2015. Norwich: TSO.

HM Treasury. 2018a. Public Expenditure Statistical Analyses 2018. Norwich: TSO.

HM Treasury, 2018b. Spring Statement 2018. Speech [Online]. Available at:

https://www.gov.uk/government/speeches/spring-statement-2018-philip-hammonds-speech [Accessed 07/09/2018].

Home Office, 2016a. Single departmental plans for 2015 to 2020 [Online]. Home Office. Available: https://www.gov.uk/government/collections/single-departmental-plans-for-2015-to-2020\#singledepartmental-plans-2015-to-2020 [Accessed 20/08/2018].

Home Office, 2016b. Home Secretary speech on fire reform (at REFORM event 24/05/2016. [Online]. Available at: https://www.gov.uk/government/speeches/home-secretary-speech-on-fire-reform [Accessed 17/09/2018].

Home Office. 2017a. Home Office single departmental plan. [Online]. Available at: https://www.gov.uk/government/publications/home-office-single-departmental-plan/home-officesingle-departmental-plan [Accessed 19/09/2018].

Home Office. 2017b. Fire and Rescue National Framework for England: Government consultation. London: TSO.

Home Office 2017c. Fire Minister's speech to Reform. Available at:

https://www.gov.uk/government/speeches/fire-ministers-speech-to-reform [Accessed 19/09/2018].

Home Office. 2018. Fire and rescue national framework for England. London: TSO.

Lowndes V and Pratchett L (2012) Local governance under the Coalition Government: austerity, localism and the big society. Local Government Studies 38(1): 21-40.

Murphy, P. and Ferry, L., 2018. Another turn of the screw: fire and rescue under the Coalition Government of 2010-2015. In: P. Murphy and K. Greenhalgh, eds., Fire and rescue services: leadership and management perspectives. London: Springer, pp. 45-59. 
Murphy, P., Ferry, L., Glennon, R. and Greenhalgh, K., 2018. Public service accountability: rekindling a debate. Cham, Switzerland: Palgrave Macmillan.

Murphy P, and Glennon, R. (2018). Why not take the time to get the fire framework right? FIRE, pp. 21-23.

National Audit Office. 2011. The failure of the FiReControl project. HC 1272 2010-2012. London. TSO.

National Audit Office. 2015a. Financial sustainability of fire and rescue services. HC 491, Session 2015-16. London: TSO.

National Audit Office. 2015b. Variation in spending by fire and rescue authorities 2011-12 to 2013-14. London: TSO.

O'Hara, M. 2015. Austerity Bites: A journey to the sharp end of the cuts in the UK. Bristol: Policy Press.

Public Accounts Committee, 2016. The failure of the FiReControl project. Fiftieth Report of Session 2010-12. London: TSO.

Public Accounts Committee, 2016. Financial sustainability of fire and rescue services Twenty-third Report of Session 2015-16. London: TSO.

Schui, F. 2014. Austerity: The Great Failure, New Haven: Yale University Press.

Scorsone E. A. and Plerhoples, C. 2010. Fiscal Stress and Cutback Management Amongst State and Local Governments: What Have We Learned and What Remains to Be Learned? State and Local Government Review Vol 42, Issue 2, pp. 176 - 187

Scottish Fire and Rescue Service. 2018. Your Service Your Voice: A consultation on the safe and planned future of the SFRS. Cambuslang: SFRS.

Scottish Government (2011a). A Consultation on the Future of the Fire and Rescue Service in Scotland. Edinburgh: Scottish Government.

Scottish Government (2011b) Initial Options Appraisal Report: Prepared for Scottish Fire and Rescue Services Ministerial Advisory Group, Scottish Government: Edinburgh.

Scottish Government (2011c) Reform of the Fire and Rescue Service in Scotland: Outline Business Case, Scottish Government: Edinburgh.

Scottish Government (2013a) Fire and Rescue Framework for Scotland, Edinburgh: Scottish Government.

Scottish Government (2013b) Scottish Fire and Rescue Service (SFRS) Governance and Accountability Framework. Edinburgh: Scottish Government.

Scottish Parliament (2011a). Financial Scrutiny Unit Briefing: The Commission on the Future Delivery of Public Service 11/52. [Online]. Available at http://www.parliament.scot/ResearchBriefingsAndFactsheets/S4/SB 11-52.pdf [Accessed 15/09/2018]. 
Scottish Parliament (2011b). Report on the Financial Memorandum of the Police and Fire Reform (Scotland) Bill. [Online] Available at:

http://www.parliament.scot/parliamentarybusiness/CurrentCommittees/48609.aspx [Accessed $18 / 09 / 2018]$

Scottish Parliament. 2018. Public Audit and Post-legislative Scrutiny Committee: Scottish Fire and Rescue Service - an update. [Online] Available at:

http://www.parliament.scot/parliamentarybusiness/CurrentCommittees/109350.aspx [Accessed 18/09/2018].

Taylor, L., Murphy, P. and Greenhalgh, K., 2018. Scottish fire and rescue services reform 2010-2015. In: P. Murphy and K. Greenhalgh, eds., Fire and rescue services: leadership and management perspectives. London: Springer, pp. 191-205.

Wilks, S. (2010). Cutback Management in the United Kingdom: Challenges of Fiscal Consolidation for the Administrative System. The Korean Journal of Policy Studies, Vol. 25, No. 1, 85-108 (2010) 